\title{
INTER SPEM ET DESPERATIONEM: DIPLOMATIC EMOTIONS OF THE HABSBURG ENVOYS AT THE OTTOMAN COURT (1553-1557)
}

\section{Zrinka Blažević}

Faculty of Humanities and Social Sciences, University of Zagreb

\section{ABSTRACT}

\begin{abstract}
This paper will focus on the emotionological analysis of selected Latin diplomatic reports written by Antun Vrančić (1551-1617) and Franciscus Zay (1498-1570), Habsburg envoys who negotiated a peace-treaty with Sultan Süleyman I and his Grand Vizier Rüstem Pasha between 1553 and 1557. Besides narrative representations of various emotional styles and states of diplomatic actors on both sides which range from hope and pride to anger and frustration, due analytical attention will also be paid to manifestations, functions and meanings of simulatio, dissimulatio and amicitia as typical features of early modern diplomatic practice. The paper will in this way provide an outline of a new diplomatic emotionology as a potentially useful heuristic model for the new actor-centred diplomatic history.
\end{abstract}

Soon after the ambitious Sultan Süleyman I came to the throne (he reigned from 1520-1566), the Kingdom of Hungary became the new target of Ottoman territorial expansions in Southeastern Europe. Ottoman military success was sealed in the famous battle near the Hungarian town of Mohács in 1526 where the Ottomans defeated the Hungarian army led by King Louis II Jagiellon (1506-1526), who died fleeing the field after the battle. Both Süleyman's victory and King Louis's death without an heir caused the Habsburgs to intervene: they wished to establish their rule in Hungary due to their family ties with the Jagiellonian dynasty. This was the beginning of the Habsburg-Ottoman conflict over the rule in South Eastern Europe which was to last for the subsequent four centuries. Although in 1526 the majority of Hungarian aristocrats chose John Zápolya (1516-1540) as the new King of Hungary under the Ottoman auspice, his election was immediately opposed by Ferdinand I Habsburg (1503-1564), who was proclaimed King of Hungary by the remaining Hungarian nobility in 1527 . The conflict between two Hungarian kings, Ferdinand and Zápolya, ended in 1540 with Zápolya's death which prompted Ottomans to capture Buda and extend their conquests in central Hungary. Thus the former Hungarian Kingdom was divided into three parts: western and northern parts were under the Habsburg rule, eastern part of the former state was reshaped into the Principality of Transylvania which was in a vassal relationship with the Ottoman Empire, while the central part of the former Hungarian state became an integral part of the Ottoman Empire. Despite the fact that the 
Ottomans handed over the power in Transylvania to Zápolya's son John Sigismund, Habsburg forces gradually conquered eastern Hungary and Transylvania. The Habsburg rule over Transylvania was supposed to be finally established by the settlement of Alba Iulia, which was concluded in 1551 between the Transylvanian Estates and Ferdinand I, but that instantly caused a new Ottoman campaign into Transylvania. ${ }^{1}$ Consequently, in the spring of 1553 , Ferdinand I decided to send a Habsburg delegation led by two learned humanists and diplomats Antun Vrančić (1504-1573) and Franciscus Zay (1489-1570) to Istanbul to obtain peace with the Ottoman Empire and to secure, through a new agreement and the payment of the annual "gift", that Transylvania remain under Habsburg rule. ${ }^{2}$

During their stay in Istanbul Vrančić and Zay kept almost daily diplomatic correspondence with the Habsburg Emperor Ferdinand I, informing him in minute detail of their negotiations with the Ottoman officials. Owing to the fact that all Vrančićs works in Latin, including his diplomatic reports, were preserved and published in 12 volumes by the Hungarian Academy of Science in the second half of the $19^{\text {th }}$ century, they can be used as an excellent source for scrutinizing early modern diplomatic practice. ${ }^{3}$ Therefore, the present paper will focus on two diplomatic reports of Habsburg envoys to Ferdinand I written at the beginning (in September 1553 ) and at the end (in August 1557) of their first Istanbul mission. ${ }^{4}$

Following the interest of the new actor-centred diplomatic history for diplomats' personal thoughts and experiences, ${ }^{5}$ the main emphasis of this article will thus

For a profound analysis of Ottoman politics towards Hungary in the second half of the $16^{\text {th }}$ century cf. Pál Fodor, The Unbearable Weight of Empire. The Ottomans in Central Europe - A Failed Attempt at Universal Monarchy (1390-1566) (Budapest: Research Centre for the Humanities, Hungarian Academy of Sciences, 2016), 162-176.

2 For an overview of Vrančić's and Zay's diplomatic mission in Istanbul cf. Anđelko Vlašić, "Introductory study," in Carigradska pisma Antuna Vrančića. Hrvatski i engleski prijevod odabranih latinskih pisama/The Istanbul Letters of Antun Vrancicic, Croatian and English Translation of Selected Latin Letters, ed. by Zrinka Blažević and Anđelko Vlašić (IstanbulZagreb: Bilnet, 2018), 24-65. The bilingual Croatian- English translation of four diplomatic letters by Antun Vrančić was generously sponsored by Turkish philanthropist Mr. Oğuz Aydemir and meticulously reviewed by Prof. Nenad Moačanin, to whom I express my deepest gratitude.

3 Cfr. Verancsics Antal, Összes munkái, ed. László Szalay and Gusztáv Wenzel, vols. I-XII, (Budapest: Eggenberger Ferdinand, 1857-1885).

4 Cfr. "XXX. Vrančić and Zay to King Ferdinand, September 1, 1553", in The Istanbul Letters, 66104; "LXXXVI. Vrančić and Zay to King Ferdinand" in The Istanbul Letters, 109-147.

5 As Tracey A. Sowerby recently observed, new diplomatic history tends to abandon narrow bureaucratic state-centric focus characteristic for traditional diplomatic history and prioritise the study of individual diplomats and monarchs, personal information networks and princely courts. Moreover, it has reinterpreted the chronology and geography of the introduction of resident ambassadors in Europe and has broadened its field of analysis to include diplomatic gifts, diplomatic ceremonies, diplomatic hospitality and other aspects of diplomatic culture. Cfr. Tracey A. Sowerby, "Early Modern Diplomatic History," History Compass vol. 14, no. 9 (2016): 441-456. 
be laid on representations of emotions as well as on various diplomatic strategies and tactics employed by the Habsburg emissaries faced with the quite rigid diplomatic stance of Grand Vizier Rüstem Pasha (1544-1553 and 1555-1561) and other Ottoman ministers. Emotional textuality, i.e. representations of various and multiple affect-eliciting experiences of Habsburg envoys articulated in their diplomatic reports provide an excellent insight into their strategic assessments of the world which oriented their political decisions and actions. This is in complete accordance with the presumptions of the political emotionology, a rapidly expanding field within contemporary political science. Drawing upon the theory of the practical consciousness and the concept of "structures of feelings" elaborated by Raymond Williams, political emotionology thus claims that political actions, which merely rest upon unreflective mental processes and habitual activities, can be regarded as an "acting out" of feelings that cannot be fully worked through and symbolized. ${ }^{6}$

Hence, following the incentives of new diplomatic history whose analytical interest is primarily focused on diplomats' own experiences and thoughts, a new intriguing research field for both diplomatic historians and International Relations scholars might be found in diplomatic emotionology. In order to scrutinize more thoroughly attitudes, behaviours and emotional styles of persons engaged in the diplomatic activities, the inspiring theoretical framework and methodological protocols for the new diplomatic emotionology could be provided by Affective Intelligence Theory (AIT). Critically distanced from the Rational Choice Model which has dominated the political science for decades, Affective Intelligence Theory rests on the assumption that affects and conscious reasoning are interdependent and complementary. For these reasons, its analytical focus is put on the interactive and highly functional dynamic balance between cognition and emotions. They govern political judgements and orient political practice. Presupposing that emotion-led judgements occur at the subconscious level, Affective Intelligence Theory is concerned with three ongoing preconscious appraisals responsible for distinct strategic tasks. The first appraisal uses the affective range that goes from depression to elation by monitoring and managing the progress of and adjustments to the actions meant to secure rewards by means previously learned. As reward-seeking actions unfold successfully, this process generates greater levels of enthusiasm or, if the contrary is the case, it leads to the frustration and even depression. The second appraisal process uses the affective range of aversion to monitor and manage the progress and adjustments of actions meant to protect and minimize punishments by means previously learned. While the mentioned two appraisal processes are con-

\footnotetext{
For a more detailed account cfr. Simon Clarke, Paul Hoggett, Simon Thomas, "Moving Forward in the Study of Emotions: Some Conclusions," in Emotion, Politics and Society, ed. by Simon Clarke, Paul Hoggett, Simon Thomas (Basingstoke: Palgrave Macmillan, 2006), 162-188.
} 
cerned with the swift assessment and control of actions that implement familiar goal seeking routines, the third uses the affective range of the emotions of anxiety and fear to scan for the unexpected. As anxiety arises, the interest in and attention to new information goes up along with a willingness to find a mode that will resolve the anxiety-producing uncertainty. For these reasons, it enables thoughtful deliberation so that learning can take place. Since described systems continually compare sensory information about the world, they are the main generators of the adaptive flexibility of human beings. ${ }^{7}$

Although Affective Intelligence Theory is mostly used in political science for the examination of voting behaviour and political communication in general, it may provide inspiring theoretical and methodological impulses for diplomatic emotionology as well.

As it has been previously argued, the primary diplomatic task of Vrančić and Zay after their arrival to Istanbul in September 1553 was to obtain the Sultan's recognition of the Habsburg's right to rule in Transylvania in exchange for the yearly tribute. However, due to the obstinate attitude of the Ottoman government, their stay in the Ottoman capital was prolonged to four years and ended with a modest success. As a matter of fact, Habsburg envoys who were in 1555 joined by a famous Flemish humanist and diplomat Ogier Ghiselin de Busbecq (1522-1592), managed to arrange a peace treaty with the Sultan Süleyman with the obligation of payment of a yearly tribute in the amount of 30,000 golden coins, but without a definite decision on the future fate of the strategically important fortress of Szigetvár which ought to be ceased to the Ottomans. ${ }^{8}$

Although Habsburg diplomats were taken to the Divan and even paid a visit to the Sultan himself, their main collocutor was Grand Vizier Rüstem Pasha who decisively declined all their requests. From his first meeting with the Habsburg diplomats, Rüstem Pasha's diplomatic strategy merely rested on the strict refusal to negotiate on Transylvania and to explicitly menace with war. ${ }^{9}$ Moreover, in their diplomatic reports addressed to the Emperor, Vrančić and Zay depicted him as a

For a more detailed account see: George E. Marcus, "How Affective Intelligence Theory Can Help US Understand Politics, https://emotionresearcher.com/how-affective-intelligencetheory-can-help-us-understand-politics/

8 Cfr. Vlašić, "Introductory Study," 45-55.

9 E.g., "Afterwards, being barely able to listen to the beginning of the speech, he immediately gestured with his outstretched hand, signalling to us to stop speaking and said that, if we wanted peace, we should not say anything about Transylvania. If, on the other hand, we were instructed to ask for Transylvania, it would be better not to even mention our mission. In that case, he said, we had come in vain." "XXX. Vrančić and Zay to King Ferdinand, September 1, 1553," 73. "Therefore, if again your King does not take into consideration the power of our Sultan and scorns his demands, let him take heed not to lose much more than what he had lost so far because we will take Vienna too." “XXX. Vrančić and Zay to King Ferdinand, September 1, 1553," 97. 
cruel and rude man who often ironized their attempts to accomplish their diplomatic duties. Although Grand Vizier's behaviour really distressed the Habsburg emissaries, they nevertheless relentlessly strove to find a successful way to carry out their diplomatic tasks.

In accordance with the best traditions of the early modern Western diplomacy, Habsburg envoys founded their diplomatic strategy on the political and juridical concept of amicitia. It presupposed a mutual favourable attitude of two equally dignified political partners who express their political will to sustain peaceful relations and restrain themselves from causing any damage to each other. As such, it was the starting point of any relationship between two independent political entities and a precondition to all interstate, peaceful and juridical relations. ${ }^{10}$ For these reasons, Habsburg emissaries constantly appealed to the Sultan's trust and benevolence towards the Emperor who claimed to be "Sultan's most faithful friend and ally". ${ }^{11}$ Consequently, he was offering to the Sultan "just", "fair" and "honourable" conditions of peace that would bring calm and rest to the subjects of both rulers. ${ }^{12}$ In opposition to this, Rüstem Pasha and other appointed Ottoman dignitaries steadily appealed to the Sultan's right of the sword, his obligation to the Prophet's word and tutelage towards those who claimed Sultan's mercy as main justifications for the rejection of all Habsburg diplomatic claims. ${ }^{13}$ At the heart of this diplomatic and cultural clash lay in fact the Western misunderstanding of the Ottoman policy which, calling upon the universal rule and regarding itself as a self-sufficient entity, could conduct only unilateral politics. Although early modern Ottoman diplomatic practice was established on the principle of mutual reciprocity and hospitality towards foreign envoys, it did not recognize the principle of equality with diplomatic partners which essentially excluded any possibility of concluding bilateral treaties. ${ }^{14}$ Therefore, in analogy to the abdnâmes which were granted to the non-Muslim communities within their own world, the peace treaty with the Habsburg Emperor was from the Ottoman perspective regarded as a unilateral truce, i.e. the expression of the ruler's autonomous will.

Faced with the mentioned obstacles and obstinate rejections from the Ottoman part, Habsburg emissaries experienced a wide range of emotions which they depicted in their diplomatic reports to the Emperor in the smallest detail. Describing

10 For a more detailed account cf. Randall Lesaffer, „Amicitia in Renaissance Peace and Alliance Treaties (1450-1530)", Journal of the History of International Law, vol. 4, no. 1 (2002): 77-99.

12 Cfr. Vrančić, "XXX. Vrančić and Zay to King Ferdinand, September 1, 1553 ”, 73.

13 Cfr. Vrančić, "XXX. Vrančić and Zay to King Ferdinand”, 88-89.

14 For an overview of the basic principles of Ottoman diplomacy cf. A. Nuri Yurdusev, "The Ottoman Attitude toward Diplomacy", in Ottoman Diplomacy. Conventional or Unconventional?, ed. by A. Nuri Yurdusev, (Basingstoke: Palgrave Macmillan, 2004), 5-35. 
their meetings with the usually ill-tempered and menacing Grand Vizier Rüstem Pasha, they often referred to their fear, even despair:

He did not listen too carefully to this, unless he had feigned it. He added that he did not understand anything else from our words than that we were pleading for a permission to return. He declared that he intended to discuss this with us in detail later. After saying this, he showed us the exit with his hand. We returned to our home full of doubt in the outcome of this entire matter. A few days later, while idly sitting, we succumbed to despair because we did not know what to do. ${ }^{15}$

However, these emotions did not prevent them from conceiving various diplomatic strategies and testing diverse negotiating tactics. Alongside the notorious practice of gift-giving and offering bribe to the Sultan and Ottoman viziers, Habsburg diplomats regularly relied on the practices of simulatio and dissimulatio as well. ${ }^{16}$ Above all, these consisted of tempering emotions and hiding emotional reactions during diplomatic negotiations with Ottoman officials. As a matter of fact, they were trying to conceal their fear and anger, which were regarded as the most undesirable diplomatic emotions, in the every possible way. ${ }^{17}$ Accordingly, in their diplomatic practice Habsburg envoys usually adopted a modest and peaceful emotional approach with deliberate but relentless verbal insistence on the issues concerning their diplomatic tasks. ${ }^{18}$ The emotional style of the Habsburg diplomats also included non-verbal language, i.e. facial expressions and bodily gestures. ${ }^{19}$ In the course of exhausting negotiations with the Ottoman dignitaries, they were

15 Vrančić, "LXXXVI. Vrančić and Zay to King Ferdinand," 112.

16 The intertwined practices of simulation (i.e., actively feigning or pretending) and dissimulation (withdrawing into silence permitting a false impression to stand) were the most advisable performative practices of the early modern diplomacy and the key features of the normative diplomatic ceremony. For a more detailed account see: J. R. Woodhouse, "Honourable dissimulation: some Italian advice for the Renaissance diplomat", Proceedings of the British Academy, no. 84 (1994): 25-50.

17 E.g. "In order for him [i.e. Rüstem Pasha] not to think that we had lost courage due to such an awful status of our task, and that we were still keeping secret what we were allowed to accept in case of emergency, we replied to him more energetically, as people who are arrogant due to their power, and who must not give up until the very end, out of any hope or shrewdness." Vrančić, "LXXXVI. Vrančić and Zay to King Ferdinand," 122.

18 E.g. "Demonstrating modesty with the expression of our faces and with the manner of our speech, we declared to him that we do not wish to do anything that could offend the almighty Sultan or His Exalted Lordship. However, we cannot keep silent and not mention what we had been instructed to say, because the orators are the means by which absent rulers talk to each other about their affairs of state." Vrančić, "XXX. Vrančić and Zay to King Ferdinand", 73.

19 On the importance of non-verbal language in the early modern diplomacy cfr. William Roosen, "Early Modern Diplomatic Ceremonial: A System's Approach," The Journal of Modern History, vol. 52, no. 3 (Sept. 1980): 452-476. 
usually used for expressing inappropriate and potentially offensive diplomatic emotions such as dissatisfaction and resentment. ${ }^{20}$ Only in rare occasions, such as during discussions on the conditions of serfs, Habsburg emissaries relied on the emotionally heightened rhetorical performance whose main function was to incite compassion and, by happy chance, to ensure easier acceptance of the Habsburg requirements on the Ottoman side:

In the moment when we were discussing the condition of serfs, we rose up from our chairs and asked him to listen to our pleas, whereat we, apart from our oratory skills, demonstrated our emotions too. And this was not in vain. Therefore, after we had finished our conversation and when we were finally instructed to sit down, we requested him to allow for the serfs - as we had asked for - to be liberated from taxes on both sides, as it had previously been discussed. ${ }^{21}$

Judging from the emotional discourse of their diplomatic reports, the most prevailing emotion of the Habsburg emissaries on the court of the Sultan Süleyman was certainly frustration, caused by their incapability to persuade Ottoman officials and carry out their diplomatic duties successfully. The clearest illustration of their helplessness is offered in the concluding sentence of the first letter to the Emperor Ferdinand written in Istanbul in September 1553: "We had tried really everything, but we did not find anything other among Turks but stubborn assiduity." ${ }^{22}$ Hence, there is no wonder that this unpleasant emotion profoundly modelled their heteroimage of the Ottomans who were characterized as "the people who have no sincere feelings for the Christians and do not know to rule or to live differently than to always have someone around to rob and to take prisoners from.. ${ }^{23}$ Together with its concomitant side-effects of desperation and anger, the frustration of the Habsburg envoys in the face of innumerable obstacles from the Ottoman part, was accompa-

20 E.g. "Then he [i.e. Rüstem Pasha] added, repeating twice: Your King cannot be trusted, your King cannot be trusted” and fell silent. Then Zay replied: 'Our King, Your Lordship the Pasha, can be trusted and I am amazed that Your Serene Lordship has such an opinion of our King, when a king can never utter a lie. Even more so it cannot be done by our King, who is the greatest of all Christian kings.' Afterwards he asked the Pasha what was the thing he did not believe Our Majesty. Then the Pasha said: 'Why did he not respect the armistice?' Zay responded: 'The King respected the armistice and it was not disturbed nor infringed by his will, but out of malice of those who did not want in any way for the most powerful Sultan and my King to live in harmony.' The Pasha then said: 'You believe this?' 'Not only do I believe this', replied Zay, 'but I know it for a fact.' Then he hung his face in sign of grief and disappointment for being forced to patiently listen to such things about his ruler, so the Pasha passed to another topic." Vrančić, "XXX. Vrančić and Zay to King Ferdinand," 87-88.

21 Vrančić, "LXXXVI. Vrančić and Zay to King Ferdinand," 101.

22 Vrančić, "LXXXVI. Vrančić and Zay to King Ferdinand," 104.

23 Vrančić, "LXXXVI. Vrančić and Zay to King Ferdinand," 92. 
nied by the feeling of disgust as well. As a consequence, putting aside all diplomatic etiquette and rhetorical politeness, in the official letter addressed to the Emperor, Ferdinand Vrančić and Zay even referred to the Ottoman capital as to "the stinking swamp." ${ }^{24}$ On the other hand, their constant experience of frustration made the Habsburg envoys more receptive to the slightest signs of hope when it seemed that the Ottoman dignitaries could meet their requests. This was especially noticeable during the negotiation on Szigetvár at the end of their Istanbul mission when they put all their efforts to encode Rusted Pasha's puzzling message on the possibilities of rendering Szigetvár intact:

Thereupon Rüstem Pasha declared: 'If your King,' he said, 'will have difficult time destroying and completely razing Szigetvár, which is a small fortress which produces much bigger expenses than is its use, warn your King to try and find a way and means by which to persuade our ruler to allow for Szigetvár to remain intact.' After hearing this from the interpreter, we were seized by great joy, the more because it was unexpected. But because we doubted the Pasha had uttered precisely these words, before we had answered the Pasha, we asked the interpreter how we should understand this Pasha's statement. 'As a bribe, he replied, which we liked very much. ${ }^{25}$

Following the propositions of Affective Intelligence Theory of three stages of affect-eliciting appraisals, it seems that diplomatic activities described in Istanbul letters by Vrančić and Zay are mostly driven by a second and a third appraisals. As a matter of fact, faced with various kinds of normative violations and uncertainty, Habsburg diplomatic envoys predominately sense emotions of aversion, anger and fear. These emotions increase solidarity among them to affirm and enable collective action, raise attention to new information on the target event on options and incite willingness to compromise in order to secure a more effective collective response. When they find their goal seeking routine working, it increases a level of their enthusiasm or, if their efforts prove less successful, they feel greater frustration or even depression. Therefore, if read through the lens of diplomatic emotionology, this constant "oscillation between hope and despair" that marked the dominant emotional state of Vrančić and Zay's Istanbul mission might render a valuable insight into political judgements, decisions and practices of the diplomatic actors involved in accordance with the recent research aims of the new diplomatic history. Moreover, it can also throw a different light on the intricate structure of the intercultural relations between European and non-European polities during the early modern "first globalization."

\footnotetext{
24 Vrančić, "LXXXVI. Vrančić and Zay to King Ferdinand," 96.

25 Vrančić, "LXXXVI. Vrančić and Zay to King Ferdinand," 122.
} 


\section{BIBLIOGRAPHY}

Clarke, Simon, Paul Hoggett, Simon Thomas. "Moving Forward in the Study of Emotions: Some Conclusions," in Emotion, Politics and Society, edited by Simon Clarke, Paul Hoggett, Simon Thomas. 162-188. Basingstoke: Palgrave Macmillan, 2006.

Fodor, Pál. The Unbearable Weight of Empire. The Ottomans in Central Europe - A Failed Attempt at Universal Monarchy (1390-1566). Budapest: Research Centre for the Humanities, Hungarian Academy of Sciences, 2016.

Lesaffer, Randall. "Amicitia in Renaissance Peace and Alliance Treaties (1450-1530).” Journal of the History of International Law, vol. 4, no. 1 (2002): 77-99.

George E. Marcus, "How Affective Intelligence Theory Can Help US Understand Politics," Accessed October 29, 2019. https://emotionresearcher.com/ how-affective-intelligence-theory-can-help-us-understand-politics/

Roosen, William. "Early Modern Diplomatic Ceremonial: A System's Approach.” The Journal of Modern History, vol. 52, no. 3 (Sept. 1980): 452-476.

Sowerby, Tracey A. "Early Modern Diplomatic History." History Compass vol. 14, no. 9 (2016): 441-456.

Verancsics, Antal. Összes munkái, edited by László Szalay and Gusztáv Wenzel, vol. I-XII. Budapest: Eggenberger Ferdinand, 1857-1885.

Vlašić, Anđelko. "Introductory study." In Carigradska pisma Antuna Vrančića. Hrvatski i engleski prijevod odabranih latinskih pisama/The Istanbul Letters of Antun Vrančić, Croatian and English Translation of Selected Latin Letters, edited by Zrinka Blažević and Anđelko Vlašić. 24-65. Istanbul-Zagreb: Bilnet, 2018.

Vrančić, Antun. Carigradska pisma Antuna Vrančića. Hrvatski i engleski prijevod odabranih latinskih pisama/The Istanbul Letters of Antun Vrančić, Croatian and English Translation of Selected Latin Letters, edited by Zrinka Blažević and Anđelko Vlašić. Istanbul-Zagreb: Bilnet, 2018.

Woodhouse, J. R. "Honourable dissimulation: some Italian advice for the Renaissance diplomat." Proceedings of the British Academy, no. 84 (1994): 25-50.

Yurdusev, Nuri A. "The Ottoman Attitude toward Diplomacy." In Ottoman Diplomacy. Conventional or Unconventional?, edited by A. Nuri Yurdusev, 5-35. Basingstoke: Palgrave Macmillan, 2004. 